\title{
Increasing voluntary savings in the USA
}

Received: 16th August, 2005

\section{Merijn Boender}

is Vice President of Diversified Investment Advisors, a leading retirement plan provider in the USA, offering a full range of defined benefit and defined contribution plans to large and very large corporations, unions and not-for-profit organisations. Diversified is part of the worldwide AEGON Group. He is part of an AEGON USA task force developing broad-based retirement solutions for pre-retirees and retirees.

\begin{abstract}
Voluntary retirement savings in the USA have seen a dramatic change in the past three decades with the emergence of the $401(\mathrm{k})$ plan. Facilitated by US Government regulations, these plans have overtaken defined benefit plans as the most utilised retirement savings vehicle, shifting the responsibility and risk of accumulating sufficient retirement income to the individual. Several key factors have contributed to the success of the $401(\mathrm{k})$ plan as the backbone of the voluntary system in the USA. There remains, however, a substantial retirement funding problem to be solved, especially for employees of smaller businesses. This paper provides a broad overview of some aspects of these factors and features. It also looks at current trends which may influence the success of voluntary savings in the USA, including those based on 'inertia', points out that such measures are in their infancy in the USA and highlights that measures to reduce inertia as well as go with the flow of it may well be needed to achieve a lasting solution.
\end{abstract}

Keywords: USA; voluntary retirement savings; defined contribution plans; pensions; education; inertia

'Old age is like everything else. To make a success of it, you've got to start young.'

Theodore Roosevelt ${ }^{1}$

\section{Introduction}

In the fast-changing world of retirement plans in the USA, the words of

Merijn Boender Vice President Diversified Investment Advisors

4 Manhattanville Road,

Purchase, New York 10577

USA

Tel: +19146978550 Fax: +19146978501 e-mail:

mboender@divinvest.com
Theodore Roosevelt seem to hold true more than ever. The shift from defined benefit plans to defined contribution plans has shifted the risk of having insufficient funds in retirement to maintain one's standard of living from the employer to the individual employee. The current heated debate about the necessity for profound change in the Social Security system highlights the question of whether the government-administered pension provision will continue to be able to transfer the risk of having retirement income sufficient to avoid poverty to collective arrangements, as was envisioned by the 'other' Roosevelt in the late 1920s.

This paper shares some views on the underlying factors and circumstances which have made the 'US system' of the three-legged stool of Social Security, employer-sponsored pensions and private savings into a reasonable success. 
There will be particular focus on education as part of the overall solution to get Americans to save voluntarily for retirement and give a practitioner's view of how this has been one of the key reasons for the success of the voluntary system.

\section{History}

As many before have very accurately described changes in the US retirement plan environment in the past three or four decades, ${ }^{2}$ this paper will only paint the historical picture with a very broad brush.

The introduction of the Social Security system 70 years ago was principally designed to combat pensioner poverty. ${ }^{3}$ The economic development of the USA and the improving healthcare standard subsequently increased the average age of Americans significantly over the course of the past century. ${ }^{4}$ The middle of the 20th century saw the emergence of defined benefit pensions, but they were mostly the prerogative of white-collar workers.

The introduction of the 401(k) plan in the early 1980s as a new variation of defined contribution plans started to change the landscape dramatically. It took the concepts of investing, asset allocation and risk-and-reward down from an elite group of institutions and wealthy individuals into a broad market of ordinary Americans. Mutual funds, new to the market, flourished with the traditional insurance companies facing strong competition in the employer-sponsored retirement market.

The stock market boom of the 1990s had two profound effects. It spurred enthusiasm of Americans to become investors even more. At the same time it masked the profound changes the defined benefit plan market underwent to a large degree. The 'contribution holidays' for employer sponsors of fully-funded plans made corporate America focus less on the underlying liabilities. At the same time, Americans grew accustomed to seeing their 401(k) and Individual Retirement Account (IRA) ${ }^{5}$ balances grow with double-digit figures and did not seem to value properly these benefits, until the technology bubble burst in the early 2000s.

In the next ten years or so, the 'baby-boomer' generation of Americans, born between 1945 and 1955, will celebrate their 65th birthdays, With this will come the first generation of Americans having to rely on the retirement funds they have accumulated by their own choice to replace pre-retirement income.

\section{Cultural differences between the USA and Europe}

The concept of 'volition' referred to in 'voluntary savings' is interesting in a comparative cultural context. It implies a level of discretion as to whether or not an individual wants to save for retirement. In several European countries, the concept of solidarity and redistribution of wealth, which has underpinned unemployment benefits, healthcare provision and old age pensions, has made individuals assume that there is something 'to fall back on' to stay out of poverty, if the individual chooses not to defer current income into retirement.

In the USA, by contrast, the expectation is that 'one has to take care of oneself, as no one else will. This awareness has only increased in recent years with the rapid inflation of healthcare and nursing home costs. ${ }^{6}$

Notwithstanding this, personal savings ratios as a percentage of disposable income in the USA have declined dramatically in the past 45 years, 


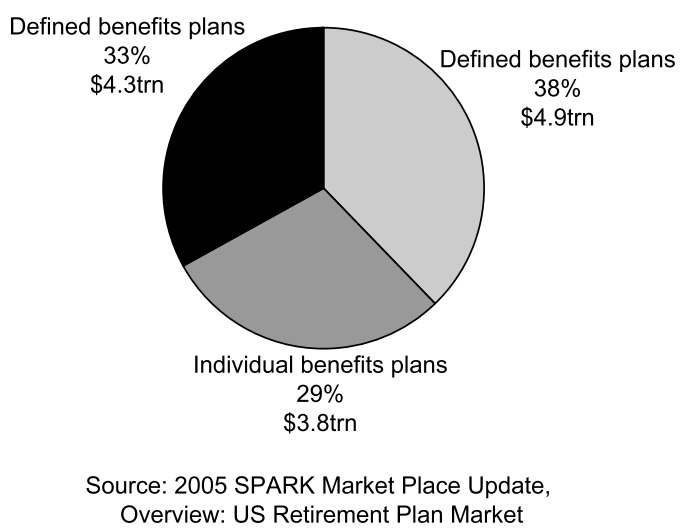

Figure 1: Pensions market assets

culminating with a high of 10.2 per cent in the early 1980s to a negative 0.1 per cent in 2000 , and a slight recovery to around 1.8 per cent in 2004 . $^{7}$

The following section will review what government and industry have done in the past 25 years to assist Americans to voluntarily build up their nest eggs.

\section{Social security}

The government-administered Social Security system continues to provide the foundation of the retirement income of most Americans. While the US Social Security benefits are generally lower than those of most Western countries' state pensions, individual Americans do end up with net replacement rates of 61.4 per cent for those individuals earning half of the average wage, 51.0 per cent for someone earning the average wage, and 39.0 per cent for someone earning twice the average wage. ${ }^{8}$ President Bush has noted the effects of the future demographic change of the US population on the pay-as-you-go system $^{9}$ and has urged the nation to contemplate structural changes to the system, including the introduction of partially privatised Social Security accounts. ${ }^{10}$ Between now and 2075. the current system is projected to run into an aggregate inflation-adjusted deficit of more than $\$ 20$ trn. $^{11}$

\section{The voluntary savings market in the USA}

The total voluntary savings market for the main types of retirement plans in the USA, measured in assets under management, is around $\$ 13$ trn. This number excludes several other products, such as variable and fixed annuities and certificates of deposit, which may be used as retirement vehicles. The $\$ 13$ trn is roughly divided in thirds between defined benefit plans, defined contribution plans and individual retirement plans (Figure 1). In the period between 1985 and 2002, the number of defined benefit plans decreased from 170,000 to around 38,000 . In the same period the number of defined contribution plans increased from 462,000 to 702,000 . In terms of assets in these plans, defined contributions plans assets increased from approximately 40 per cent of total private plan assets to approximately 60 per cent between 1992 and 2002. ${ }^{12}$

What is behind the success of defined contribution retirement plans? 


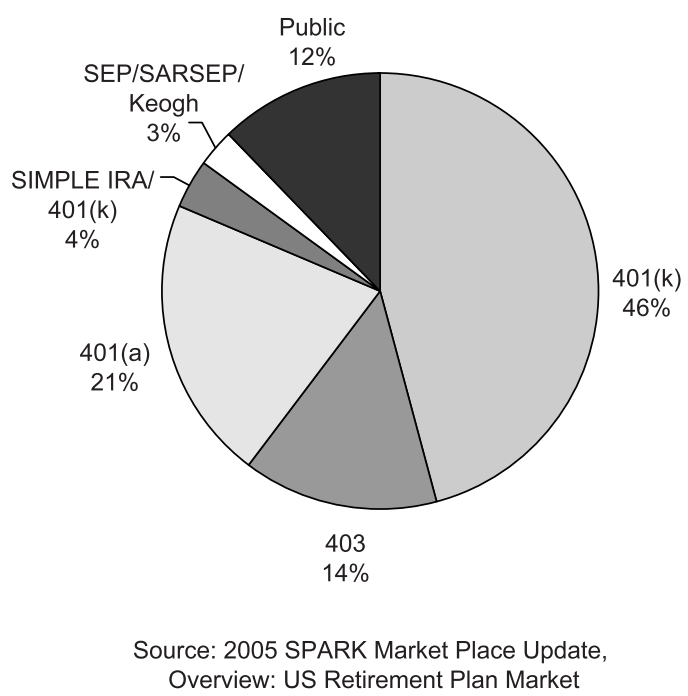

Figure 2: Defined contribution plans

\section{The 401(k) plan: A story of 'reasonable success'}

On balance, the voluntary savings system in the USA, as a complement to Social Security and a substitute for declining defined benefit plan savings has been a success. The reason for qualifying it as a 'reasonable success' will be explained below.

Private sector defined contribution plans accounted for $\$ 3,779 \mathrm{bn}$ of assets at the end of 2003 (Figure 2). ${ }^{13}$

The way 401(k) plans have been structured can be called truly voluntary. First of all, the US Government has chosen not to mandate employers to offer these types of retirement plans, ${ }^{14}$ or to force them to make employer contributions. ${ }^{15}$ Instead the US Government has introduced an elaborate set of regulations under the Employee Retirement Income Security Act of 1974 (ERISA) and other legislation to regulate how employer-sponsored retirement plans are to be offered. A combination of 'carrots and sticks' has been developed over time to encourage employers to actively offer retirement plans to their employees and to encourage employees to participate in these plans.
The key yardsticks of success are obviously the degree with which people actually use the plan to provide for retirement income and the ultimate income that they provide for themselves.

\section{Participation rates}

According to the Employee Benefits Research Institute, participation rates of 401(k) plans show considerable variation by industry, company size, geographical location and age and income levels of employees. The overall level of those employees participating in employment-based retirement plans in 2003 was at 42.0 per cent, while the percentage of full-time, full-year wage and salary workers aged 21-64 (those most likely to be offered a retirement plan at work) increased from 56.7 per cent in 2002 to 57.1 per cent in $2003 .{ }^{16}$ To be clear, these numbers include all those employees who are working for an employer whether or not they are offered a retirement plan.

Key to this is the limited number of small and very small employers offering any type of retirement plan to their 
Table 1: Reasons for participating in a $401(\mathrm{k})$ plan

\begin{tabular}{ll}
\hline Percentage citing reason & $\begin{array}{l}\text { Reason for participating in a } \\
\text { 'very important' }\end{array}$ \\
\hline Concern about funding retirement & 85 \\
Company match $^{\star \star}$ & 67 \\
Tax-deferred status of contributions & 64 \\
Payroll deduction feature & 55 \\
Ability to take a hardship from the plan & 23 \\
Ability to take a loan from the plan** & 19 \\
Advice from friend or family members & 15 \\
Advice from fellow employees & 10 \\
\hline
\end{tabular}

*Multiple responses allowed

${ }^{* \star}$ Asked of those offered the feature

Source: Investment Company Institute

Table 2: Reasons for not participating in a $401(\mathrm{k})$ plan

\begin{tabular}{ll}
\hline Percentage citing reason as & $\begin{array}{l}\text { Reasons for not participating in a 401(k) plan* } \\
\text { 'very important' or 'somewhat important' }\end{array}$ \\
\hline Do not have extra money to save & 66 \\
Household is saving for retirement in another way & 57 \\
Dislike plan features & 36 \\
Plan features are confusing & 32 \\
Advice from family member, friend, or & 31 \\
professional financial advisor & \\
\hline
\end{tabular}

*Multiple responses allowed

Source: Investment Company Institute

employees. To illustrate the huge

variation in participation rates: only 16.5 per cent of employees of companies with fewer than 10 employees participated in a plan, compared with 60.3 per cent of those working for an employer with 1,000 or more employees. ${ }^{17}$

Looking at $401(\mathrm{k})$ plans, participation rates seem to be higher, at around 72 per cent. ${ }^{18}$ This suggests that, once the hurdle of getting the plan sponsor to offer the plan is overcome, a significant majority of employees chooses to participate.

In 2004 LIMRA researched participation factors, in particular the influence of plan features on participation in 401(k) plans (Table 1). ${ }^{19}$

Key factors for eligible employees to participate are the realisation that they have to do something about their retirement, and the employer matching contribution. The ability to access the funds when needed plays a role, but to a lesser degree.

The reasons for not participating were also investigated (Table 2).

The first reason in Table 2 is directly related to the increasing level of personal debt, through credit cards, personal loans, car loans, as well as house prices which, in spite of low interest rates, has forced many Americans to take on more debt than in previous decades.

As shown in Table 3, older Americans are more inclined to participate.

Conversely, participation rates among younger generations are low. LIMRA pointed at various possible reasons, such as short-term goals like saving for a house or paying off personal debt.

The total number of participants in 401(k) plans increased from 7.5 million in 1984 to 47.2 million Americans in 2002.

A factor to keep in mind looking at 
Table 3: Decision to participate by age

\begin{tabular}{lll}
\hline & Percentage who participate & $\begin{array}{l}\text { Percentage who do not } \\
\text { participate }\end{array}$ \\
\hline $21-29$ & 61 & 39 \\
$30-39$ & 72 & 28 \\
$40-49$ & 77 & 23 \\
$50-59$ & 78 & 22 \\
$60-69$ & 72 & 28 \\
\hline
\end{tabular}

$\mathrm{N}=41,085$

participation rate numbers is job mobility in the USA, ${ }^{20}$ and the fact that historically many retirement plans have had requirements, such as completion of a certain period of service to be eligible to enrol in the plan. ${ }^{21}$

Further, it is very important to consider that employer sponsored plans are not the only way to save for retirement in the USA in a tax-advantaged way. There is a wide variety of variable and fixed annuities ${ }^{22}$ and other retail savings products, such as individual retirement accounts, SIMPLE IRAs and Keogh plans, which are widely used to accumulate retirement funds.

\section{Deferral ratios and replacement ratios}

Participating in a 401(k) plan has so far typically required a conscious decision by employees to participate in the plan and defer a certain percentage of their income. ${ }^{23}$ Their ultimate retirement success of course depends not only on that decision, but also on the total sum of money they manage to defer during their working lifetime. Their investment success throughout the accumulation stage will determine how much of their final income they can replace in a 'secured' or 'unsecured' way. As the levels of annuitisation of $401(\mathrm{k})$ funds have been traditionally low, asset allocation and investment growth during retirement have become a new area of attention.
For a number of years there has been quite a lively debate in the USA about what the appropriate replacement rate should be to incorporate in education and illustrations to end consumers.

Traditional models will recommend replacement ratios of 75 per cent. However, the rapid rise in healthcare costs has led commentators to suggest higher replacement ratios (Figure 3).

Average deferral rates in $401(\mathrm{k})$ plans in 2002 were around 6.5 per cent of the employee's salary, which on average amounted to approximately $\$ 3,047$. This includes the employer matching contribution, where applicable. Typically, the employee contributes 3 per cent, and the employer matches 50 per cent of this contribution. More generous 401(k) plan sponsors may match 100 per cent of the first 3 per cent and 50 per cent of an additional 3 per cent of the employee's contribution.

LIMRA found that average participation rates as well as deferral rates increase with age (Figure 4). ${ }^{24}$

In dollar terms, the average deferral rate is considerably lower than the maximum allowable contribution of $\$ 11,000 .^{25}$ The 6.5 per cent deferral rate should provide a 25 -year-old earning $\$ 40,000$ and contributing for the next 40 years his 75 per cent replacement ratio (including Social Security benefits) until the age of 85 , provided the investment return on average is 8.5 per cent or more (Figure 3). ${ }^{26}$ 


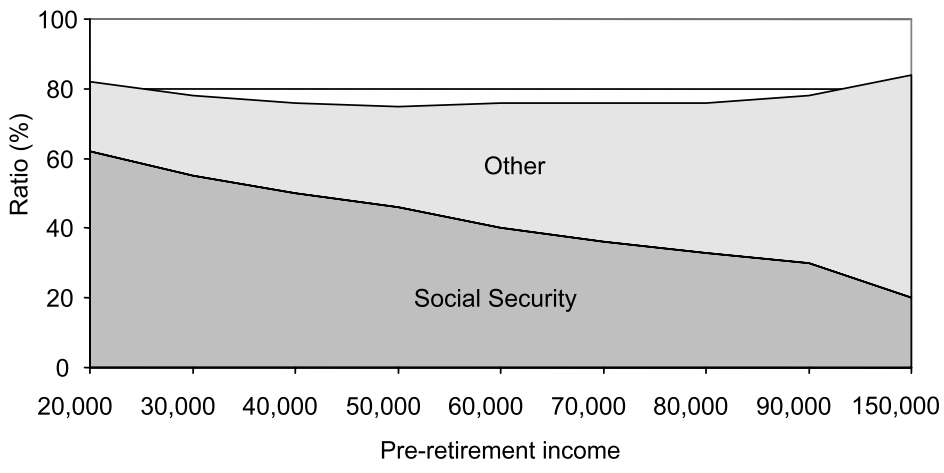

Source: Lynn Miller (2002) EBRI: Issue Brief \#243, quoting Fred Munzenmaier and Jeff Paciero (2001) 'Replacement Ratios and Phased Retirement - A New Tune on an Old Fiddle', AON Consulting and Georgia State University.

Figure 3: Replacement ratios by income level

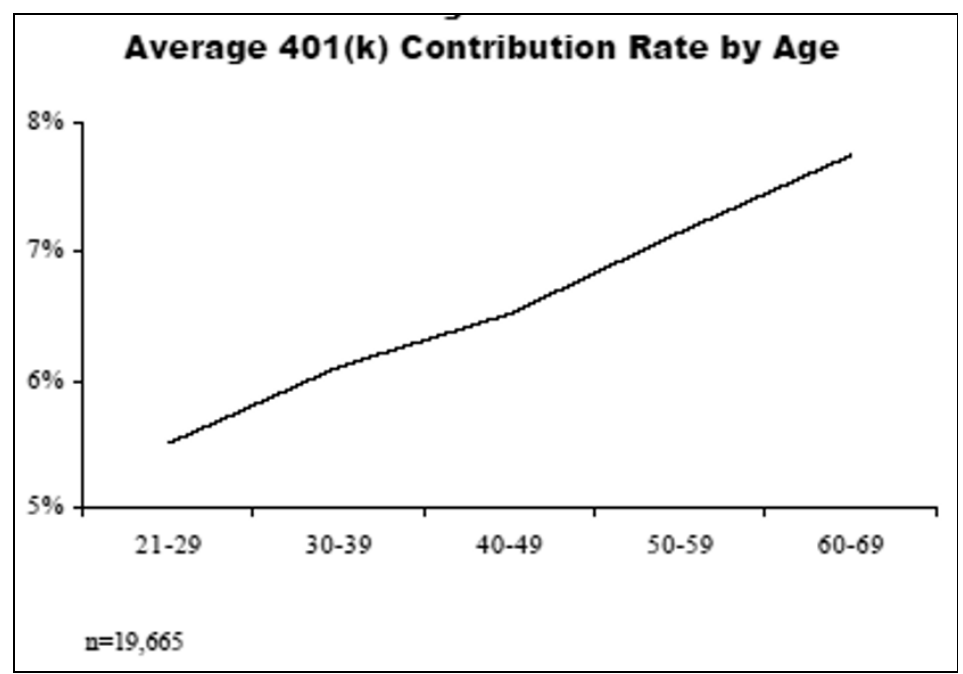

Figure 4: Average 401(k) contribution rate by age

\section{Success factors of the voluntary savings market}

Beyond looking at each of the individual factors which have contributed to the success of voluntary savings programmes in the USA, especially the $401(\mathrm{k})$ plan, one has to look at the combined effects of these measures together, implemented and cultivated over a prolonged period of time. If one wants to focus on one factor in particular, education is truly the key factor that has made it all work.

\section{Environment}

A significant segment of the American working population seems to be aware of the need to 'do something about their own retirement, as no one else will', as evidenced by participation in employer sponsored retirement plans and the take-up of individual retirement arrangements. It is hard to gauge to what extent the remaining part of the population is saving insufficiently or not saving at all. Home equity may play a substantial part in the ultimate funding 
for retirement of many Americans. That 'doing something' may not be the same as 'doing enough' is evident when looking at average deferral rates. This may be related to the fact that less than half of Americans have attempted to calculate how much money an individual needs to save for retirement. ${ }^{27}$

\section{Employer matching contribution}

Americans are susceptible to the message of 'free money', even if it is conditional upon putting some of their own money in first. This has clearly shown to be the most powerful incentive to get employees to participate. The educational message that people are 'leaving money on the table' has been easy to deliver. LIMRA's research in 2004 showed that plans with no employer matching contributions have average participation rates of only 34 per cent. Employer plans with a match saw 86 per cent of their eligible employees participate. Employer contributions have been on the decline in recent years, though, from 83 per cent of companies making a contribution in 1995 to only 77 per cent in $2002 .^{28}$

The matching contribution has the added benefit that people have to make an active decision to do something first themselves. This in essence created a double negative for the inert, but at the same time emphasises the personal responsibility of the individual.

\section{Tax facilitation}

Closely following the argument of employer contributions to get people to participate is the tax deductibility of employer and employee contributions. On the employer side, contributions are business expenses reducing the corporate tax bill. ${ }^{29}$ For the employee, even at generally lower personal income tax rates than in most European countries, the argument of the government subsidy in terms of a lower tax bill is convincing to help decide on deferring some of their income into the future. ${ }^{30}$

For lower income groups, which are paying little or no income tax, tax deductibility is less effective. For this group a Saver's Tax Credit of up to $\$ 2,000$ has been introduced. ${ }^{31}$

As with most defined contribution plan structures around the world, the employee defers taxation on contributions as well as investment gains until after retirement and is only taxed when benefits are taken out. Unlike, for example, personal pensions in the UK, the Internal Revenue Service (IRS) has never wanted to make it impossible to take money out of a $401(\mathrm{k})$ plan. Instead a 10 per cent penalty tax is levied over distributions before the age of 59.5 , in addition to ordinary income tax. Some exceptions to this rule are described below.

\section{Payroll deduction}

One of the key novelties of the Section 401(k) legislation when it was introduced was the element of payroll deduction of contributions. ${ }^{32}$ This created 'saving by stealth'. Rather than having to write cheques every month or seeing a considerable chunk of income being put away for the next 30 years, instead of being able to spend it right then and there, once employees had made the decision to participate in the plan, they would more or less go on 'auto-pilot' and start building up a fund. In a few years, they discovered a handsome sum of money on their quarterly statements and probably wondered how saving this much money had been so painless.

\section{Non-discrimination rules and testing}

As noted above, the US Government 
chose to focus on regulation of how plans should be administered and impose certain fiduciary responsibilities on the employer as a trustee and/or administrator of the $401(\mathrm{k})$ plan in order to protect employees. It decided not to mandate employers to offer such plans.

This created the situation whereby the setting up and maintaining of an employer-sponsored plan turned out to be no easy task. With no compulsion to make any type of plan available, and only the competitive pressures of the labour market to encourage employers to offer a plan, the IRS proposed with the Tax Reform Act 1984 to require non-discrimination testing to ensure that contributions or benefits under tax-qualified plans do not discriminate in favour of highly compensated employees by more than an allowable amount.

Annually, each plan is tested to determine the participation rate and average deferral percentage of eligible employees in two categories: non-highly compensated employees (the 'rank and file') and highly compensated employees (typically the senior management of the company). The results of the annual testing determine the personal tax deductibility of the category of highly compensated employees, as well as whether the plan is 'qualified' under the Internal Revenue Code.

This does not mean that executives of companies with plans with low participation among the lower echelons of the company cannot build a pension pot for themselves. Companies can institute non-qualified retirement plans, which are part of the employer's general assets rather than held in trust, and do not have the tax benefits of qualified retirement plans. Benefits are paid at the retirement age in the form of annuities or in lump sum payments, which are taxed as ordinary income and which cannot be transferred to an IRA to further defer taxes.

\section{Safe harbour regulations}

In 1996 and 1998 the IRS introduced legislation for businesses to circumvent non-discrimination rules, by creating 'safe harbours' for employers. If certain requirements in the plan's design are met, the employer is exempted from annual testing. These include immediate vesting for 100 per cent of the matching and non-elective contributions. The base formula for matching contributions is 100 per cent of elective deferrals up to 3 per cent of compensation and then 50 per cent of elective deferrals on the next 2 per cent of compensation, or a more generous formula. The basic philosophy is that the generosity of the plan for all employees will encourage take up by itself, and the employer should not be punished for the employees' decision not to take the offer.

\section{Flexibility: Loans, hardship withdrawals, disability withdrawals}

The psychological impediment of locking in money for a long time and not having access to it is difficult for many people to overcome, in the USA as much as elsewhere in the world.

Taking this into consideration, 401(k) plans allow for certain liquidity features for prescribed situations, in which the participant can take a distribution from his plan without incurring the 10 per cent penalty tax. ${ }^{33}$ These are loans, hardship withdrawals and disability withdrawals.

Loans are principally under control of the plan sponsor, who specifies the rules under which loans can be taken, such as the maximum amount ${ }^{34}$ and the number of loans which can be outstanding at the 
same time. The participant pays interest to himself. ${ }^{35}$ Often, this feature is included to lower the threshold to participate. The downside of taking a loan is that the repayments to the plan have to be made with after-tax dollars and, if the participant defaults on the loan, the whole amount is taxed.

LIMRA research has indicated that while many plan sponsors feel compelled to offer loans, there is no significant difference in the participation rates of plans with a loan facility versus a plan which does not allow loans.

Hardship withdrawals are also not required by the government to be included in the plan design. ${ }^{36}$ The IRS defined hardship withdrawals with four key conditions. The withdrawal is necessary due to an immediate and severe financial need. The withdrawal is necessary to satisfy that need (ie the money cannot be obtained elsewhere). The amount of the loan does not exceed the amount of the need. And the participant has already obtained all distributable or non-taxable loans available under the $401 \mathrm{k}$ plan. If these conditions are met, the funds can be withdrawn and used for one of the following five purposes:

1 A primary home purchase;

2 Higher education tuition, room and board and fees for the next 12 months for the participant, spouse, dependants or children;

3 To prevent eviction from home or foreclosure on the primary residence;

4 Severe financial hardship; or

5 Tax-deductible medical expenses that are not reimbursed for the participant, spouse or dependants.

Hardship withdrawals are subject to the 10 per cent penalty tax and ordinary income tax.

The IRS waives the 10 per cent tax penalty (although the investor must still pay taxes on non-financial hardship withdrawals), in the following five situations:

1 The participant becomes totally and permanently disabled;

2 Medical debts exceed 7.5 per cent of your adjusted gross income;

3 A court of law has ordered the participant to give the funds to the divorced spouse, a child, or a dependant;

4 The participant is permanently laid off, terminated, quit, or retired early in the same year they turned 55 or later; or

5 The participant is permanently laid off, terminated, quit, or retired and has established a payment schedule of regular withdrawals in equal amounts of the rest of their expected natural life. Once the first withdrawal has been made, the investor is required to continue taking them for five years or until they reach the age of 59.5, whichever is longer.

\section{Barriers against take-up of 401(k) plans}

Perceived lack of funds seems to be the primary factor holding Americans back from participating in and contributing to a $401(\mathrm{k})$ plan available to them.

Inertia seems to be another key factor, fuelled by the complexity of the issue in front of them and possible negative psychological associations, such as old age and death.

Lack of active employer involvement, especially in the small and medium size business is also a crucial factor.

But none of these factors seem to have fundamentally changed since the 1980s when $401(\mathrm{k})$ plans were first introduced. Consumerism, the continuing gradual erosion of the virtuous culture of frugality and saving, increased house 
prices, college tuition fees and health care costs all will have increased the pressure on individual Americans facing the challenges of retirement.

What then has made the big difference, contributing to the success of the democratization and spread of the 401(k) plans?

\section{Education}

Key to the success of the $401(\mathrm{k})$ plan has been the persistent education

programmes which have been developed and perfected by providers and distributors over the past three decades. The US Government took care of creating the necessary environment in which saving for retirement would be relatively easy, advantageous, flexible and rewarding to those who stay the course. The industry responded by creating the programmes and systems to deliver these effectively to the mass market. As the 401(k) market emerged, competition among competitors fostered innovation, especially in the area of education.

The adage 'Pensions are sold, not bought' seems to be as true for the USA, as it is for the rest of the world. The decision to forego instant gratification and choose instead a deferred potentially enhanced gratification at some point in the future is as rational as it is counterintuitive to many.

The complexity of personal needs and preferences, including attitudes towards risk, combined with a large number of external variables, such as expected returns, employment security and financial requirements, make it difficult for ordinary people to understand what to do.

The decision of the US Government to encourage employers to take an active role as plan sponsors has had a number of extremely beneficial effects. First of all, many have chosen to take an active stance and sponsor retirement plans, where - it should be remembered they have a choice not to.

In addition, employers quickly realised that the value of the plan they sponsored is only as good as employees give the employer credit for doing so. The first step in that process is to encourage employees to participate in the plan. Then, continued communication is required to remind employees of the value of the benefits sponsored.

Employers also realised that they themselves are neither equipped nor skilled to develop and deliver education programmes effectively. Providers and distributors at the same time realised they had the capabilities to add value and increase the attractiveness of their $401(\mathrm{k})$ plans for employers and employees. Soon, they found themselves competing with peers on the quality of their education programmes.

In the smaller and medium-sized plan market, ${ }^{37}$ education and/or advice is normally provided by a broker directly to employees. Many brokers rely on plan providers to develop and in some cases deliver the education packages, such as enrolment kits, seminars, one-on-one meetings, dedicated customer contact centres and promotional materials.

Plans sponsors routinely query plan providers about the quality and the proven success of their participant education programmes. Participant education is part of the pricing of plans.

Larger plan sponsors typically negotiate in detail with plan providers about the type and frequency of enrolment meetings, investment education meetings, customised materials or even entire custom-made campaigns to address the specific issues of that plan sponsor.

The spreading of technology in the past decade, especially the emergence of the internet, has transformed interaction between participants and plan providers. 
Access to websites with daily valuations, funds switches, web-based education meetings, streaming videos have all helped to enhance the ways in which plan participants can be educated and can educate themselves about preparing for retirement.

This has had limited effect, however, on those who have not started to save yet. Unchanged is that the most effective way to persuade is face-to-face, preferably in a one-on-one setting to explain to the individual employee the benefits of enrolling in the employer-sponsored retirement plan.

Plan providers still employ sizeable teams of enrolment and education specialists travelling around the country to conduct on-site meetings. Some very large retirement plan sponsors are willing to pay for full-time enrolment specialists employed by the plan provider, to be based at one or more of the plan sponsor's sites to explain the plan and its benefits to eligible employees and educate existing plan participants about asset allocation, deferral sufficiency, diversification and related topics.

\section{Guidance versus advice}

One of the reasons that plan sponsors and providers are happy to provide education to plan participants about highly sensitive topics such as investing in a country as litigious as the USA, is that the Department of Labor has created a regulatory framework which delineates clearly what providers and distributors can and cannot do. ${ }^{38}$

A distinction is made between investment guidance and investment advice.

The Department of Labor (DOL) determined that the furnishing of the following categories of information and materials to a participant or beneficiary in a participant-directed individual account pension plan will not constitute the rendering of 'investment advice', irrespective of who provides the information (eg plan sponsor, fiduciary or service provider), the frequency with which the information is shared, the form in which the information and materials are provided (eg on an individual or group basis, in writing or orally, or via video or computer software), or whether an identified category of information and materials is furnished alone or in combination with other identified categories of information and materials. ${ }^{39}$ The categories are:

- plan information;

- general financial and investment information;

- asset allocation models; and

- interactive investment materials.

Stopping short of providing investment advice in this way, the industry has been able to avoid the significant added infrastructure and cost related to the fiduciary responsibility and liability associated with participants investing.

In practice though, the creation of this 'guidance' space has allowed for mass-customisation of investment information, which has proved effective to serve the needs of very large groups of employees. Of course, there is a vibrant market for investment advice, which is used by many people who feel investment guidance is not meeting their needs.

Recently, plan sponsors have tended to move more in the 'advice' direction, or at least make investment advice available. As plan providers are prohibited from providing investment advice related to 'affiliated funds', ${ }^{40}$ providers are increasingly arranging for third-party professional investment managers to provide managed accounts and plan-sponsored advice to participants. 


\section{Charges}

Just a few words on charges and fees. These vary significantly according to a great deal of factors, including the size and complexity of the plan, the scope of the services rendered to the plan by distributor and provider, the range of investment options and many others. Invariably, these fees and charges are under significant competitive pressure in a market where there are hundreds of 401(k) providers vying for a large, but limited market.

Education, be it guidance or advice, carries a cost to be delivered to employees. The most difficult task may be to provide information to eligible employees and assist them in their decision whether or not they want to participate. As explained above, there are different ways of doing this, and all of them carry different levels of costs and remuneration to deliver them in an economically viable way.

Examples of retirement plans are not mentioned here, as they may not be very meaningful in an international comparison; they are influenced by so many factors that only a very elaborate comparison would find American apples matched with apples in various European countries. The author's strong impression, based on two years of observing competitive pricing in the USA is that across the board, most $401(\mathrm{k})$ plans in the USA - perhaps with the exception of the largest ones - carry a fully loaded cost which is at or above the 1 per cent of assets under management.

\section{Recent trends and innovation}

Automatic enrolment is undoubtedly the hot topic in the USA currently. Several retirement plan oriented bills currently pending in the 109th Congress propose introducing this plan design feature into law. ${ }^{41}$ The concept is simple: new employees are automatically enrolled in the plan, unless they choose to opt out, thus using inertia in a positive way.

Technically this has been possible for a number of years already and some employers struggling with participation issues have tested this new method, with varying degrees of success.

There are a number of issues which will have to be worked out going forward. Investments could be directed in no-risk money-market funds, or asset allocation funds, which over the long term may or may not match the appropriate risk-reward consideration of especially younger investors. As discussed above, the standard deferral rate at which employees are automatically enrolled would likely be lower than appropriate in the long term to provide the employee with a reasonable chance to achieve a significant replacement ratio.

Practically, in view of the frequent job changes of employees, the maintenance cost of these many small accounts, of which the 'inactive' owner may not always be easy to trace, may become an issue.

The key is that it gets people saving, even if by default. To turn the passive saver into an active one, a considerable effort is likely to be required.

Another way to use inertia to the benefit of the employee is a method which was developed in academic circles and is now finding its way into industry practice: the Save More Tomorrow. Professors Shlomo Benartzi of UCLA and Richard $\mathrm{H}$. Thaler of the University of Chicago worked on the same principle of saving by stealth which proved to be so successful with payroll deduction in the 1980s. Again the concept is simple: upon enrolment the employee agrees that with each future pay rise, their deferral percentage will increase. The industry has welcomed the concept with considerable enthusiasm 
and the next few years will tell if this feature enters the mainstream of $401(\mathrm{k})$ plans.

The long-term effect of inertia-based methods is not yet known. The extent to which 'levelling down' or substitution of the inertia-based savings for some existing other form of (not necessarily pensions) saving may detract from the overall effectiveness of inertia-based approaches in building the total provision for retirement. Measures which 'go with the flow' of inertia, but do not aim to actually do anything to reduce the amount of inertia - via education and other measures to increase consumer engagement - may ultimately not be wholly successful. A sensible policy would have to include measures both to reduce inertia as well as to make use of it.

Asset allocation funds are growing in popularity. The debate between open-ended strategic allocation funds and funds with a target maturity date is undecided as yet, but seems to move in the direction of the latter. These funds seem a good way to address the desire among employees for simplicity and understanding, as they help employees decide an investment strategy from amidst the plethora of investment options in 401(k) plans.

A major issue for a number of years has been the cashing out of small balances of $401(\mathrm{k})$ plans upon job changes. To preserve these smaller balances for the purpose they were originally intended for, ie retirement funding, in March 2005 the Department of Labor issued regulation regarding $401(\mathrm{k})$ balances of terminated employees between $\$ 1,000$ and $\$ 5,000$. Where previously plan sponsors were inclined to force these relatively costly accounts out of the plan, now these are automatically rolled over into an Individual
Retirement Account (IRA). The hope is that the investor will either roll this balance into an IRA, possibly adding other balances from other previous employers and preserve it for retirement, rather than spending it.

Finally, there is the President's Savings Proposal, tabled by the Bush

Administration, during the first term in office which introduced the concept of Lifetime Savings Accounts (LSAs), Retirement Savings Accounts (RSAs) and Employer Retirement Savings Accounts (ERSAs). These are tied in with the President's proposal to simplify the Internal Revenue Code. These are designed to reduce the restrictions on access to individual funds, ${ }^{42}$ or to simplify the current range of defined contribution plan types. ${ }^{43}$

As President Bush has placed his tax reform plans on hold for the moment and faces considerable challenges concerning his Social Security plan, it is hard to predict if and when these plans will take shape.

\section{Conclusion}

Thinking back to Theodore Roosevelt's words, voluntary savings in the USA have come a long way. Whether it started young depends on the eye (and age) of the beholder. Whether it has reached old age yet, will only be known a few decades from now.

Whether it has been a success so far is also a matter of judgment. For the 45 million Americans who have built up a nest egg in their 401(k) plan, which will allow them to retire in the next decade with more than FDR's Social Security, it is fair to say it has been quite a success.

Above all making a voluntary savings system a success requires the best of all parties concerned, the government, the industry, employers and employees alike. 


\section{References}

1 Some ascribe this quote to Fred Astaire.

2 See recent concise overview by DeGennaro, R. P. and Murphy, D. L. (2004) 'The expanding role of defined contribution plans in the USA: Benefits, restrictions and risks', Pensions, Vol. 9, No. 4, pp. 308-316.

3 President Franklin D. Roosevelt signed the law creating the Social Security programme on 14th August, 1935.

4 The average life expectancy of a 65-year-old increased from 15.8 years in 1960 to 19.0 years in 1990 and is expected to rise further to 24.0 years in 2010, according to research by Matthew Greenwald Associates in 2001.

5 The Individual Retirement Account (IRA) is an individual tax-deferred retirement plan, which can accept rollovers from qualified retirement plans such as $401(\mathrm{k})$ plans and is often used when individuals change jobs or enter into retirement, not wanting to leave their retirement funds in the employer-sponsored plan.

6 According to the 2004 Health Confidence Survey, of the Employee Benefits Research Institute (EBRI), concerns about healthcare rank statistically at the same level as terrorism and national security and ahead of issues of the war in Iraq, the economy and education (available at: www.ebri.org).

7 News Release, 'Personal income and outlays: June 2005', US Department of Commerce Bureau Economic Analysis, 2nd August, 2005 (available at: www.bea.doc.gov).

8 OECD (2005) 'Pensions at a Glance: Public Policies Across OECD Countries', 2005 edn. Organisation for Economic Co-operation and Development, Paris (available at: www.oecd.org/els/social/ageing/PAG).

9 The Social Security Trust Fund was reported to stand at about $\$ 1.36 \mathrm{trn}$ at the end of 2003 ; it is projected to grow until 2017 due to the surplus of payroll taxes received over benefits paid, however, this is in the form of interest-bearing government securities or securities whose principal and interest are government guaranteed; further observations can be found in: John, D.C. (2004) 'Misleading the public: How the Social Security Trust Fund really works', Executive Memorandum No. 940 of the Heritage Foundation, 2nd September.

10 Presented as part of President Bush's drive towards an 'ownership society' these accounts, adopting elements of the Federal Thrift Savings Plan, carry similarities with the UK system of contracting out of the second state pension, and would allow individuals to self-invest part of the 11 per cent payroll tax, and achieve returns higher than the current assumed rates under the public system. Public support of the individual accounts as a way to alleviate the pressure on Social Security funding has so far been limited.

11 Mitchell, D.J. (2001) 'Social Security's \$20trn shortfall: Why reform is needed', Backgrounder No. 1194; Weller, C. (2001) 'The commission's straw man, Social Security well prepared for retirement of baby boomers in 2016', EPI Issue Brief No. 159, 19th July.

12 Source: US Department of Labor Welfare Benefits Administration.

13 Public sector defined contribution plans amounted to $\$ 527 \mathrm{bn}$ at the end of 2004 , bringing total assets in private and public defined contribution plans to $\$ 4,306 \mathrm{bn}$; source: SPARK Market Place Update (2005).

14 As is the case in the UK since the introduction of the stakeholder pension in 2001.

15 Or other types of compulsory savings schemes, as is the case in Australia and Singapore with the superannuation schemes.

16 Copeland, C. (2004) 'Employment-based retirement plan participation: Geographic differences and trends', EBRI Issue Brief No. 274, October, Employee Benefit Research Institute, Washington DC.

17 Ibid.

18 Byrne, N. (2004) 'Influence of 401(k) plan features on participation', LIMRA International, Windsor, CT.

19 Ibid.

20 Americans are said on average to change jobs between six and nine times in their lives.

21 According to Spectrum Group Research in 2002, only 18 per cent of plans has immediate eligibility, 30 per cent had 90 days or less, 18 per cent had 91-180 days, and 34 per cent had an eligibility requirement of between 181 days and one year.

22 According to the National Association for Variable Annuities (NAVA), at the end of the first quarter of 2005 , variable annuity net assets stood at $\$ 1.1 \mathrm{trn}$; according to LIMRA (Beatrice, D.Q. and Drinkwater, M. (2005) 'Individual Annuity Market: Sales and Assets', 18th July), fixed annuities for 2004 accounted for $\$ 566 \mathrm{bn}$ of assets.

23 Different from defined benefit plans, where practice seems to have been to enroll new employees upon eligibility (typically with one year waiting time and a vesting schedule).

24 Byrne, N. (2004), op. cit.

25 The Internal Revenue Service has gradually increased annual $401(\mathrm{k})$ contribution limits from $\$ 10,500$ in 2001 to $\$ 14,000$ in 2005.

26 Diversified Investment Advisors' Defer ${ }^{\mathrm{TM}}$ Estimator, available at: www.divinvest.com; this includes a Social Security entitlement, based on the current system.

27 Helman, R., Mathew Greenwald \& Associates, Salisbury, D., Paladino, V. and Copeland, C. (2005) 'Encouraging workers to save: The 2005 Retirement Confidence Survey', EBRI Issue Brief No. 280, April, Employee Benefit Research Institute, Washington DC.

28 Source: Spectrum Group research (2002).

$29 \mathrm{Up}$ to 25 per cent of compensation for all employees.

30 Similar tax breaks apply to alternative retail savings products such as variable and fixed annuities. 
31 The Retirement Savings Tax Credits is intended for people with adjusted gross incomes of less than $\$ 50,000$ for married couples filing jointly or for a single payer earning $\$ 25,000$ in adjusted gross income, and provides a tax credit of up to $\$ 2,000$.

32 In 1981, three years after the introduction of section 401(k) of the Internal Revenue Code, The IRS issued proposed regulations on $\mathrm{s} .401(\mathrm{k})$ that sanctioned the use of employee salary reductions as a source of retirement plan contributions; source: EBRI (2000) 'History of 401(k) plans', December. Available at: www.ebri.org.

33 The distribution is still taxed as ordinary income.

34 Typically the lower of 50 per cent of the balance or $\$ 50,000$.

35 Typically the prime rate plus 2 per cent.

36 Byrne, N. (2004) op. cit. found that 66 per cent of plans allow hardship withdrawals, only 4 per cent of participants use them.
37 Defined in the USA typically as companies with fewer than 500 to 1,000 employees.

38 Department of Labor, Interpretive Bulletin 96-1.

39 401k Helpcenter website: www. $401 \mathrm{kHelpCenter.com.}$

40 Department of Labor, Prohibited Transaction Exemption 77-4.

41 Retirement Savings and Security Act, s.1359 (Smith Conrad), introduced 6th September 2005 is one of the leading ones.

42 The proposed RSAs would replace Roth IRAs and the proposed LSAs have great similarities with the current Roth IRA as well. The Roth IRA is funded with after tax contributions, but provides tax relief after it has been held for a certain period.

43 The ERSA would replace qualified retirement plans [401(k), 403(b) (a variation for not-for-profit-organisations) and 457 plans (for state and local governmental entities)] and roll them all into one simplified regime. 